medRxiv preprint doi: https://doi.org/10.1101/2021.07.12.21260358; this version posted July 16, 2021. The copyright holder for this preprint

(which was not certified by peer review) is the author/funder, who has granted medRxiv a license to display the preprint in perpetuity.

It is made available under a CC-BY-NC 4.0 International license .

\title{
Increase in SARS-CoV-2 seroprevalence in healthy blood donors after the second wave of COVID-19 pandemic in South-Eastern Italy: evidence for asymptomatic young individuals as potential virus spreaders
}

Authors: Francescopaolo Antonucci (https://orcid.org/0000-0003-2536-1980)1,2, Josè Ramòn Fiore ${ }^{2,3}$, Lucia De Feo ${ }^{1}$, Tommaso Granato ${ }^{1}$, Mariantonietta Di Stefano ${ }^{3}$, Giuseppina Faleo $^{3}$, Ahmed Mohamed Farhan Mohamed ${ }^{4}$, Maurizio Margaglione ${ }^{5}$, Michele Centra ${ }^{1}$, Teresa Antonia Santantonio ${ }^{3}$

\section{Affiliations:}

1. Transfusion Medicine Center, University Hospital "Riuniti” of Foggia, Foggia, Italy

2. These authors contributed equally to this article and share first authorship

3. Department of Clinical and Experimental Medicine, Section of Infectious Diseases, School of Medicine, University Hospital “Riuniti” of Foggia, Foggia, Italy

4. Department of General Courses, College of Applied Studies and Community Service, Imam Abdulrahman Bin Faisal University, Dammam, Saudi Arabia

5. Department of Clinical and Experimental Medicine, Section of Genetics, School of Medicine, University Hospital “Riuniti” of Foggia, Foggia, Italy

Corresponding author: Josè Ramòn Fiore

Corresponding author email: jose.fiore@unifg.it

\begin{abstract}
:
Background: Italy has been the first among western countries to experience SARS-CoV-2 spread during which the southern regions were also heavily affected by the pandemic. To understand and monitor properly the evolution of COVID-19 pandemic, population based seroprevalence studies are a valid tool for the infection rates and effective prevalence of the SARS-CoV-2. Aim: In this prospective study, we assessed the changes in SARS-CoV-2 seroprevalence rates among non-vaccinated blood donors in South-Eastern Italy over May 2020 to March 2021. Methods: 8,183 healthy blood donors referring to the Transfusion Center at the University Hospital "Riuniti" of Foggia (Italy) for blood donation in the period May 2020-March 2021 were tested for anti-SARS-CoV-2 antibodies by Ortho Clinical Diagnostics VITROS ${ }^{\circledR} 3600$. None of the considered subjects had a diagnosed symptomatic COVID-19 infection. Results: Overall, 516 resulted positive for anti-SARS-CoV-2 IgG antibodies (6.3\%, 95\% CI, 0.03-0.15\%), 387 (4.7\%) were male and 129 (1.7\%) female. A statistically significant increase in the seropositive population was found from May 2020 to March 2021 (Fisher's p<0.001). The difference of the seroprevalence was significant in terms of age but not sex (2-sided $\mathrm{p}<0.05$ for age; 2-sided $\mathrm{p} \geq 0.05$ for sex) in both groups. Conclusion: Our study shows a significant increase in the SARS-CoV-2 seroprevalence among blood donors and suggests a potential role of asymptomatic individuals in continuing the spread of the pandemic. These results may contribute to establishing containment measures and priorities in vaccine campaigns.
\end{abstract}

Keywords: COVID-19; seroprevalence; SARS-CoV-2; antibodies; vaccination; asymptomatic patients.

Conflict of interest: None declared. 
medRxiv preprint doi: https://doi.org/10.1101/2021.07.12.21260358; this version posted July 16, 2021. The copyright holder for this preprint

(which was not certified by peer review) is the author/funder, who has granted medRxiv a license to display the preprint in perpetuity.

It is made available under a CC-BY-NC 4.0 International license .

\section{INTRODUCTION}

The Coronavirus Disease 2019 (COVID-19) pandemic resulted in more than 176 million cases and more than 3.5 million deaths worldwide as of June $13^{\text {th }}, 2021$ [1-2], putting a strain on the healthcare, economic and social system worldwide.

Italy has been the first among western countries to experience SARS-CoV-2 spread with a heterogeneous geographical distribution of the pandemic during the first wave (dramatic in the northern regions and more contained in the southern regions), but much more homogeneous in the second wave during which the southern regions were also heavily affected by the pandemic.

In June 2021, the number of COVID-19 infections resulted in more than 4 million cases in Italy [2], of which more than 250 thousand in Apulia (Southern Eastern Italy) [3]. A cumulative incidence of 625.6 per 10,000 inhabitants has been estimated in this region, and 6,545 deaths were recorded with a lethality rate of $2.6 \%$ [3].

The accurate assessment of antibodies seroprevalence during a pandemic can provide important information on pathogen exposure in the population [4-8]. In this regard, seroprevalence surveys in blood donors are recognized as valuable tools for refining estimates of infection and transmission [9-15].

In this prospective study, we assessed the anti-SARS-CoV-2 seroprevalence rates among non-vaccinated healthy blood donors in Foggia (South-Eastern Italy) over the period May 2020-March 2021. 
medRxiv preprint doi: https://doi.org/10.1101/2021.07.12.21260358; this version posted July 16, 2021. The copyright holder for this preprint

(which was not certified by peer review) is the author/funder, who has granted medRxiv a license to display the preprint in perpetuity.

It is made available under a CC-BY-NC 4.0 International license .

\section{METHODS}

\section{Study population}

Between May 2020 and March 2021, 8,183 blood donors referring to the Transfusion Center at the "Ospedali Riuniti" University Hospital, Foggia (Italy) for blood donation were enrolled in the study. Exclusion criteria were active infections or medical conditions, reported risk factors for parenterally acquired infections, chronic degenerative conditions, diagnosis of cancer, or high risk of cardiovascular events. Clinical examination, medical history, and biochemical testing were performed on all donors. No recent symptoms COVID-19 related, nor close contact with confirmed cases or suspected cases had to be present in all subjects. None of the subjects had been vaccinated for SARS-CoV-2 infection.

Each blood donor signed an informed consent to be enrolled in the study.

\section{Detection of anti-SARS-CoV-2}

Qualitative determination of serum total anti-Sars Cov 2 antibodies was performed as described elsewhere [16]. Briefly, the commercially available anti-SARS-CoV-2 Total reagent kit (Pencoed Bridgend, UK), a chemiluminescent immunoassay using mouse monoclonal human antibodies labelled with horseradish peroxidase (HRP) was used. Positive samples were then tested for the presence of specific $\lg G$ antibodies using the anti-SARS-CoV-2 IgG reagent kit (Pencoed Bridgend, UK).

\section{$\underline{\text { Statistical methods }}$}

Descriptive statistics was used to analyze the results. In particular, the Chi-square test and Fisher's exact test were used to compare seropositive and seronegative donors' characteristics and analyse the progressive increase of seroprevalence rates. Contingency tables were created to compare different donor characteristics. The estimated crude prevalence rate was adjusted according to the test's sensitivity and specificity. All the analysis was performed using the SPSS software package (version 19.0) and Windows Excel $^{\circledR}$. 
medRxiv preprint doi: https://doi.org/10.1101/2021.07.12.21260358; this version posted July 16, 2021. The copyright holder for this preprint

(which was not certified by peer review) is the author/funder, who has granted medRxiv a license to display the preprint in perpetuity.

It is made available under a CC-BY-NC 4.0 International license .

\section{RESULTS}

Among the 8183 blood donors enrolled as a whole, 516 (6.3\%) were tested positive for anti-SARS-CoV-2 IgG antibodies (Table 1). A statistically significant increase in the seropositive population was found from May 2020 to March 2021 (Figure 1) (Fisher's $p<0.001)$.

Blood donors were divided into two groups by considering the donation period. Individuals in the first group were donors attending blood donation in May-September 2020, whereas blood donors of the second group were enrolled from October 2020 to March 2021. The first group included 4,018 people (2,958 men and 1,060 women, mean age 34 years), and the second group 4,165 people (3,178 men and 987 women, mean age 49 years) (Table 2). A statistically significant difference $(2$-sided $p<0.001)$ of the seroprevalence rates was found between the two groups. The first group showed a seroprevalence of $0.5 \%(95 \% \mathrm{Cl}$, $0.00-0.51 \%)$, while the second group showed a seroprevalence of $11.9 \%(95 \% \mathrm{Cl}, 0.08-$ $0.10 \%)$. A higher percentage of seropositivity was detected in the second group in all age categories (Table 2).

The difference of the seroprevalence was significant in terms of age but not sex (2-sided $p<0.05$ for age; 2 -sided $p \geq 0.05$ for sex) in both groups (Table 2).

None of the anti-SARS-CoV-2 positive subjects had a diagnosed symptomatic COVID-19 infection. 
medRxiv preprint doi: https://doi.org/10.1101/2021.07.12.21260358; this version posted July 16, 2021. The copyright holder for this preprint (which was not certified by peer review) is the author/funder, who has granted medRxiv a license to display the preprint in perpetuity.

It is made available under a CC-BY-NC 4.0 International license .

Table 1:

Anti-Sars-CoV-2 seroprevalence in blood donors during the period May 2020-March 2021.

\begin{tabular}{|l|c|c|c|}
\hline $\begin{array}{c}\text { Period } \\
\text { (Month/year) }\end{array}$ & $\begin{array}{c}\text { Donors } \\
\text { (No) }\end{array}$ & $\begin{array}{c}\text { Anti-Sars-CoV-2 } \\
\text { seropositives } \\
\text { (No) }\end{array}$ & $\begin{array}{c}\text { Crude prevalence rate for } \\
\text { seropositive donors } \\
(\%)\end{array}$ \\
\hline May 2020 & 883 & 9 & 1.0 \\
\hline June'20 & 789 & 11 & 1.4 \\
\hline July '20 & 645 & 10 & 1.6 \\
\hline August'20 & 667 & 8 & 1.2 \\
\hline September'20 & 901 & 12 & 1.3 \\
\hline October '20 & 834 & 13 & 1.6 \\
\hline November'20 & 560 & 38 & 6.8 \\
\hline December '20 & 826 & 90 & 10.9 \\
\hline January '21 & 796 & 85 & 10.7 \\
\hline February '21 & 798 & 149 & 18.7 \\
\hline March '21 & 484 & 91 & 18.8 \\
\hline Total & 8183 & 516 & 6.3 \\
\hline
\end{tabular}

Table 2:

Demographic characteristics of 8183 blood donors tested for SARS-CoV-2 antibodies from May 2020 to September 2020 (Group 1) and from October 2020 to March 2021 (Group 2).

\begin{tabular}{|c|c|c|c|c|c|c|c|c|c|}
\hline \multirow{2}{*}{\multicolumn{2}{|c|}{ Cts }} & \multicolumn{4}{|c|}{ Group 1} & \multicolumn{4}{|c|}{ Group 2} \\
\hline & & Total & Seropos. & Seropos. & P-value & Total & Seropos. & Seropos. & P-value \\
\hline \multirow{2}{*}{ Sex } & $M$ & 2958 & 12 & 0.4 & \multirow{2}{*}{0.30} & 3178 & 375 & 11.8 & \multirow{2}{*}{0.63} \\
\hline & $\mathrm{F}$ & 1060 & 7 & 0.6 & & 987 & 122 & 12.4 & \\
\hline \multirow{6}{*}{ Age } & $18-25$ & 876 & 5 & 0.6 & \multirow{6}{*}{0.027} & 154 & 71 & 46.1 & \multirow{6}{*}{$<0.001$} \\
\hline & $26-35$ & 1410 & 13 & 0.9 & & 218 & 97 & 44.5 & \\
\hline & $36-45$ & 1308 & 1 & 0.1 & & 634 & 122 & 19.2 & \\
\hline & $46-55$ & 278 & 0 & 0 & & 2113 & 131 & 6.2 & \\
\hline & $56-65$ & 138 & 0 & 0 & & 981 & 75 & 7.6 & \\
\hline & $>65$ & 8 & 0 & 0 & & 65 & 1 & 1.5 & \\
\hline
\end{tabular}

Cts: Characteristics; F: Female; M: Male; Seropos.: Seropositives. 
medRxiv preprint doi: https://doi.org/10.1101/2021.07.12.21260358; this version posted July 16, 2021. The copyright holder for this preprint (which was not certified by peer review) is the author/funder, who has granted medRxiv a license to display the preprint in perpetuity.

\section{It is made available under a CC-BY-NC 4.0 International license.}

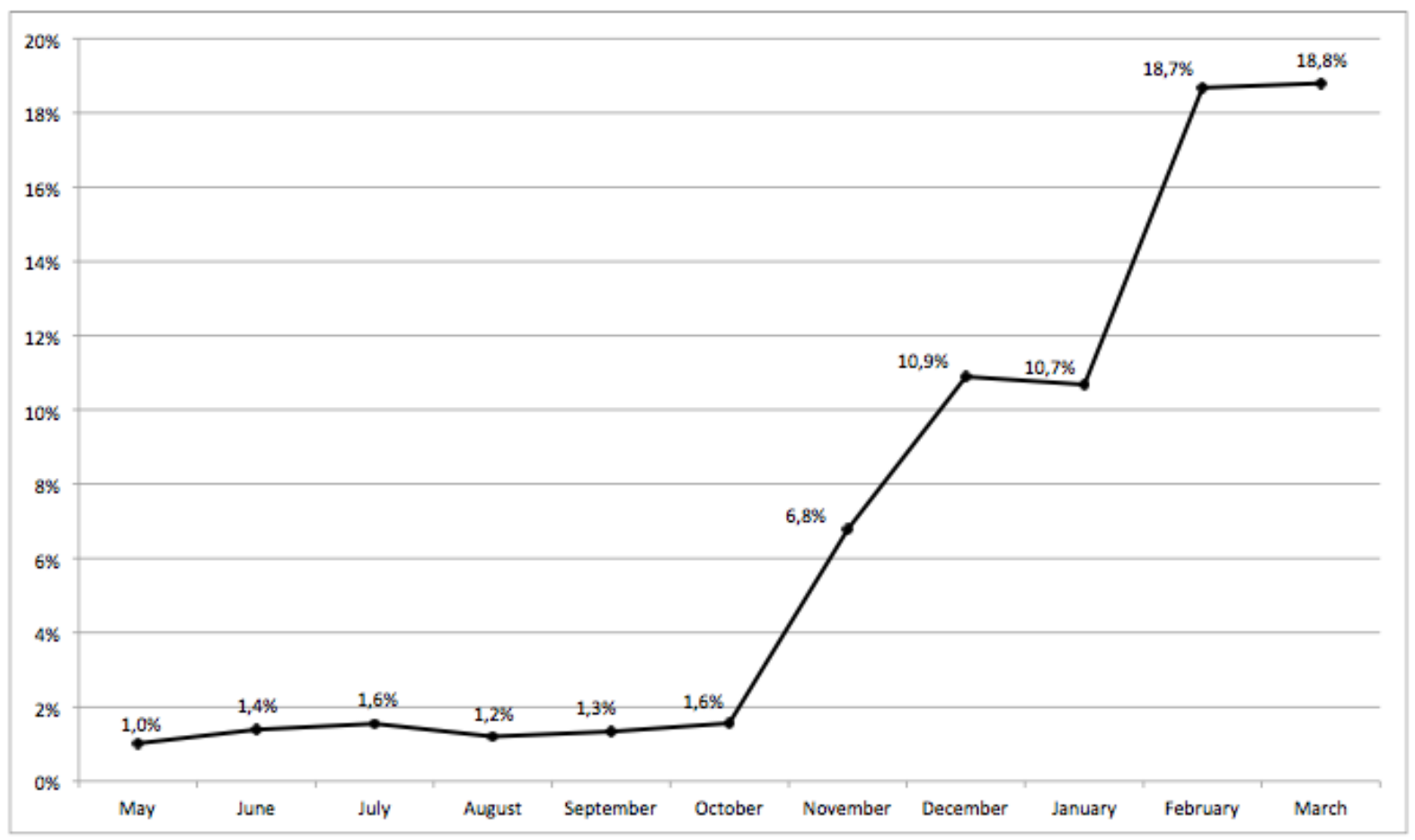

Figure 1: Cumulative percentage of seropositive blood donors in the period May 2020March 2021. 
medRxiv preprint doi: https://doi.org/10.1101/2021.07.12.21260358; this version posted July 16, 2021. The copyright holder for this preprint

(which was not certified by peer review) is the author/funder, who has granted medRxiv a license to display the preprint in perpetuity.

It is made available under a CC-BY-NC 4.0 International license .

\section{DISCUSSION}

In this study, we expanded a previous anti-SARS-CoV-2 seroprevalence survey among blood donors [17] and analysed 8,183 donors in the period May 2020-March 2021, including the first and the second waves of the COVID-19 pandemic in Italy.

In this large cohort of blood donors, we demonstrated a dramatic increase in terms of seroprevalence of anti-SARS-CoV-2 antibodies from $0.2 \%$ in May 2020 to $18.8 \%$ in March 2021.

Notably, none of the seropositive blood donors had been diagnosed as having experienced signs or symptoms of COVID-19 infection, and none had been subjected to vaccination. Thus, our survey provides a more accurate read of seroprevalence across subjects with asymptomatic infection, considered an essential source for SARS-CoV-2 transmission, but not detected by the national healthcare system.

The marked increase of seroprevalence observed over time is related to the progress of the pandemic in Italy.

After the first wave of the COVID-19 pandemic, Italy experienced very restricted containment measures for 69 days from March 9 to May 19, 2020, which dramatically reduced the COVID-19 burden in the whole country. The decreased number of new infections induced an unfounded optimism, which favoured a loss of adherence to preventive measures. Particularly during summer, relaxation of mobility reductions occurred, and several people traveled for vacation through regions with different prevalence rates, facilitating virus spread nationwide. Gathering on the beaches, crowded pubs, and discotheques were quite common during the "COVID-free" summer. All these behaviors had devastating effects in tourist areas and especially among young individuals. Moreover, the reopening of schools in September probably contributed to a rapid increase in the number of infections among young individuals who are often asymptomatic but contagious, causing intra-family COVID-19 clusters.

Consequently, from September and with more evidence in October and November, a rapid spread in newly diagnosed infections was observed nationwide.

The analysis of the results in the two groups of blood donors, based on two different pandemic periods, clearly mirrors the evolution of the pandemic. The significant difference of the seroprevalence between Group 1 and 2 highlights the impact of containment 
strategies during the initial pandemic, which helped the reduction of SARS-CoV-2 circulation among the population, and confirm, in turn, the effects of the less restrictive containment actions applied in the summer period, that vanified such effects.

Apart from the general increase of blood donors positive for SARS-CoV-2 antibodies over time, we observed that the seroprevalence rate was low among all age categories in the first group. On the contrary, in the second group, the seroprevalence rate increased in all age categories, with the youngest groups showing the higher seropositive rates.

These data are of concern as young people have an active social life and may easily transmit the infection to others. To reduce the risk of transmission from asymptomatic people, measures such as wearing masks, hand hygiene, social distancing remain mandatory until individuals are widely immunized by vaccination. So far, young subjects have not been considered a priority population in vaccination campaigns. However, the critical role of young asymptomatic individuals in future SARS-CoV-2 spread, including viral variants, suggests a rapid extension of vaccination in this setting.

In conclusion, our study shows a significant increase in the SARS-CoV-2 seroprevalence among non-vaccinated blood donors and suggests a potential role of asymptomatic individuals in continuing the spread of the pandemic. The results of this study may contribute to establishing containment measures and priorities in vaccine campaigns.

\section{CONFLICT OF INTERESTS}

The authors declare that there are no conflicts of interest. 
medRxiv preprint doi: https://doi.org/10.1101/2021.07.12.21260358; this version posted July 16, 2021. The copyright holder for this preprint

(which was not certified by peer review) is the author/funder, who has granted medRxiv a license to display the preprint in perpetuity.

It is made available under a CC-BY-NC 4.0 International license .

\section{REFERENCES}

1. European Centre for Disease Prevention and Control [Accessed June 13 2021]; available from: https://www.who.int/emergencies/diseases/novel-coronavirus-2019/situation-reports/;

2. Epidemia Covid-19. Aggiornamento Nazionale-ISS [Accessed June 13 2021]; available from: https://www.epicentro.iss.it/coronavirus/sars-cov-2-sorveglianza-dati;

3. Bollettino Epidemiologico Regione Puglia [Accessed June 7 2021]; available from: https://www.regione.puglia.it/web/press-regione/-/bollettino-epidemiologico-regione-puglia-7giugno-2021;

4. Michele Carbone, John Lednicky, Shu-Yuan Xiao, Mario Venditti, Enrico Bucci. Coronavirus 2019 Infectious Disease Epidemic: Where we are, what can be done and hope for. Journal of Thoracic Oncology; 2021 January. Doi: https://doi.org/10.1016/j.jtho.2020.12.014;

5. Didier Raoult. How useful is serology for COVID-19? International Journal of Infectious Diseases 2021; 102:170-1. Doi: http://dx.doi.org/10.1016/j.ijid.2020.10.058;

6. Michael P. Bush, Mars Stone. Serosurveillance for severe acute respiratory syndrome coronavirus 2 (SARS-CoV-2) incidence using global blood donor populations. Clinical Infectious Disease 2021; 72:254-6.

Doi: http://dx.doi.org/10.1093/cid/ciaa1116;

7. Maher A. Sughayer, Asem Mansour, Abeer Al Nuirat, Lina Souan, Mohammad Ghanem, Mahmoud Siag. Dramatic rise in seroprevalence rates of SARS-CoV-2 antibodies among healthy blood donors: the evolution of a pandemic. International Journal of Infectious Diseases 2021. Doi: https://doi.org/10.1016/j.ijid.2021.04.059;

8. Oyungerel Byambasuren, Claudia C. Dobler, Katy Bell, Diana Patricia Rojas, Justin Clark, Mary-Louise McLaws, et al. Comparison of seroprevalence of SARS-CoV-2 infections with cumulative and imputed COVID-19 cases: Systematic review. PlosOne, April 2, 2021. Doi: https://doi.org/10.1371/journal.pone.0248946;

9. Zhenyu He, Lili Ren, Juntao Yang, Li Guo, Luzhao Feng, Chao Ma, et al. Seroprevalence and humoral immune durability of anti-SARS-CoV-2 antibodies in Wuhan, China: a longitudinal, population-level, cross-sectional study. The Lancet, March 20, 2021. Doi:

https://doi.org/10.1016/S0140-6736(21)00238-5;

10. Eric R. A. Vos, Gerco den Hartog, Rutger M Schepp, Patricia Kaaijk, Jeffrey van Vliet, Kina Helm, et al. Nationwide seroprevalence of Sars-CoV-2 and indentification of risk factors in the general population of the Netherlands during the first epidemic wave. BMJ Journals, 2020. Doi: http://dx.doi.org/10.1136/jech-2020-215678;

11. Liu Anding, Li Ying, Wan Z, Wang W, Lei X, Lv Y. Seropositive prevalence of antibodies against SARS-CoV-2 in Wuhan, China. JAMA Netw Open. 2020.

Doi:10.1001/jamanetworkopen.2020.25717;

12. Fiona P. Havers, Carrie Reed, Travis Lim, Joel M. Montgomery, John D. Klena, Aron J. Hall, et al. Seroprevalence of antibodies to Sars-CoV-2 in 10 sites in the United States, March 23-May 12, 2020.

Doi: 10.1001/jamainternmed.2020.4130;

13. Amy K. Winter, Micaela E. Martinez, Felicity T. Cutts, William J. Moss, Matt J. Ferrari, Amalie McKee, et al. Benefits and challenges in using seroprevalence data to inform models for measles and rubella elimination. Doi: 10.1093/infdis/jiy137; 
medRxiv preprint doi: https://doi.org/10.1101/2021.07.12.21260358; this version posted July 16, 2021. The copyright holder for this preprint

(which was not certified by peer review) is the author/funder, who has granted medRxiv a license to display the preprint in perpetuity.

It is made available under a CC-BY-NC 4.0 International license .

14. Chris R. Triggle, Devendra Bansal, Hong Ding, Md Mazharul Islam, Elmoubashar Abu Baker Abd Farag, Hamad Abdel Hadi, et al. A Comprehensive review of viral characteristics, transmission, pathophysiology, immune response, and management of SARS-CoV-2 and Covid-19 as a basis for controlling the pandemic. Frontiers of Immunology; 2021 February. Doi:

10.3389/fimmu.2021.631139;

15. Wagner Gouvea dos Santos. Impact of virus genetic variability and host immunity for the success of COVID-19 vaccines. Biomedicine \& Pharmacotherapy; 2021 January. Doi: https://doi.org/10.1016/j.biopha.2021.111272;

16. Di Stefano M., Sarno M., Faleo G., Farhan Mohamed A.M., Lipsi M.R, De Nittis R., et al. Low Prevalence of Antibodies to SARS-CoV-2 and Undetectable Viral Load in Seropositive Blood Donors from South-Eastern Italy. Acta Haematologica 2021. doi: 10.1159/000515258;

17. Fiore J.R., Michele Centra, Armando De Carlo, Tommaso Granato, Annamaria Rosa, Michelina Sarno, et al. Results from a survey in healthy blood donors in South-Eastern Italy indicate that we are far away from herd immunity to SARS-CoV-2. Journal of Medical Virology 2021

Mar;93(3):1739-1742. Doi: 10.1002/jmv.26425. 